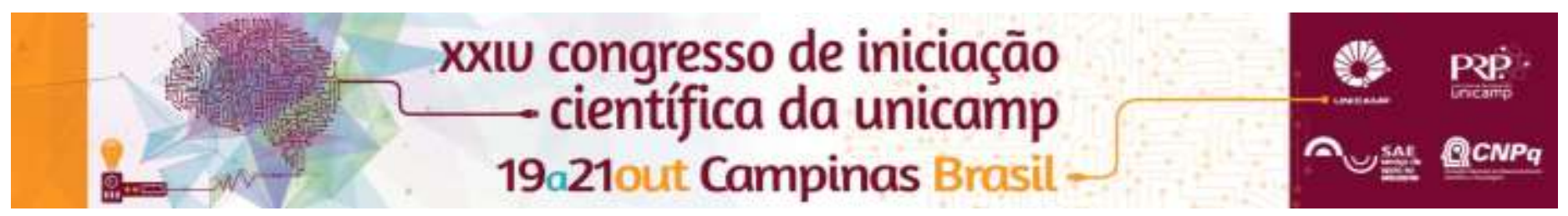

\title{
Repertório de Viola de Braço do século XVIII com ênfase no Classicismo.
}

\author{
Bruno D. R. Geremias*
}

\section{Resumo}

Este projeto foi elaborado através de um levantamento de categoria documental do repertório para viola de braço do período que se estende ao longo do séc. XVIII, além de uma análise estrutural de um concerto para viola e orquestra do compositor Antônio Rosetti.

Palavras-chave: viola de braço, repertório, período clássico, análise.

\section{Introdução}

Desde o século XVIII a viola tem sido utilizada na orquestra e na música de câmara como preenchimento da harmonia, frequentemente na sombra dos demais instrumentos de cordas, como o violino. Atualmente, a maioria das peças dos períodos barroco e clássico interpretadas na viola, são transcrições de músicas originalmente escritas para outros instrumentos. Foi realizada a busca de algumas obras compostas para viola pouco lembradas ou interpretadas, mas com grande potencial lírico e virtuosístico. Espera-se com isso ampliar o nível de conhecimento sobre este assunto para facilitar o acesso por músicos e pesquisadores que tenham interesse em buscar informações a respeito.

\section{Resultados e Discussão}

As peças do período clássico possuem uma estrutura muito simples, no entanto elas exigem mais recursos técnicos e uma sonoridade refinada por parte do intérprete.

As peças trabalhadas durante o projeto foram:

\section{Viola Concerto in G major}

Rosetti, Antônio (1750 - 1792)

Foi a peça mais analisadas durante o projeto, através de análise harmônica e interpretativa.

\section{Six Duos Pour um Violon et Alto}

Ludwig August Lebrun (1752 - 1790)

Nos limitamos a executar os duos buscando uma interpretação musical para conhecimento do estilo do compositor, porém sem realizar gravações.

\section{Trio Sonata in B-flat major for Viola and Clavier}

Graun Johann Gottlieb (1703 - 1771)

Observamos que suas composições eram bastante peculiares, algumas totalmente estruturadas nas antigas formas barrocas, enquanto outras moldadas nas formas do classicismo.

\section{Concerto pour Viola et Orchestre - Eb Major}

Karl Friedrich Zelter (1758-1832)

Concerto muito similar ao de Antônio Rosetti, porém apresenta recitativos no primeiro e no terceiro movimento, com um ritmo mais maleável. $\mathrm{O}$ caráter operístico é evidente, especialmente no terceiro movimento, devido a esses recitativos.

\section{Conclusões}

No período clássico, a viola adquire maior independência, com número de composições apresentando considerável crescimento em relação ao período barroco. Ao analisarmos as peças pesquisadas do século XVIII, podemos perceber que a viola assume um lugar significativo na performance musical, incluindo diversas formas musicais e vários tipos de combinações instrumentais: Duos, Trios e Concertos. Todas as peças possuem analisadas riqueza técnica e sonora com alta qualidade.

\section{Agradecimentos}

Ao meu orientador Emerson Luiz de Biaggi por ter me ajudado e me instruir em todos os meus passos acadêmicos.

À Unicamp, Pibic, PRP, CNPq e ao SAE por me incentivarem e permitirem o meu início na área científica.

STRAETEN, Edmund (1968). The History of the Violin: Its Ancestors and Collateral Instruments, Ed. Da Capo Press: Adivision of Plenum Publishing Corporation 227 West 17th Street New York.

ZEYRINGER, Fransz. Literatur für Viola, Ed. Neue Erweiterte Ausgabe 1985: University of Michigan.

Dicionário Grove de Música: edição concise, Ed. Jorge Zahar; Rio de Janeiro 1994 (Versão traduzida do "The Grove Concise Dictionary of Music) 